\title{
Optimization and Performance of Moderate Combined Alkali and Microwave Pretreatment for Anaerobic Digestion of Waste-Activated Sludge
}

\author{
Hao Jiang, Ting Liu, Jiangtao Ding, Hong Nie, Hongjun Zhou* \\ Institute of New Energy, State Key Laboratory of Heavy Oil Processing, Beijing Key Laboratory \\ of Biogas Upgrading Utilization, China University of Petroleum, Beijing 102249, China
}

Received: 12 May 2017

Accepted: 29 July 2017

\begin{abstract}
For pretreating waste-activated sludge, the combined alkali and microwave pretreatment is a promising hybrid method. To make this pretreatment more economical, moderate conditions were applied for central composite design of the experiments. A quadratic model was established to describe the influence of $\mathrm{NaOH}$ dosage and microwave processing time on methane production. The optimal condition was $0.12 \mathrm{~g} \mathrm{NaOH} / \mathrm{g}$ TS treatment for $24 \mathrm{~h}$ and $240 \mathrm{~W}$ microwave treatment for $10 \mathrm{~min}$. Either single or hybrid pretreatment can significantly accelerate the hydrolysis, but the degree of degradation increases positively as correlated with treatment intensity. Comparing to untreated sludge, the methane yields of microwave-, alkali-, and combined-treated increased to $1.9,3.4$, and 4.6 times, respectively. The SCOD removal rates of the three kinds of treated sludge were $20.6 \%, 23.0 \%$, and $36.5 \%$, respectively. The single microwave pretreatment efficiently broke the sludge flocs and promoted the release of biodegradable organics as well as nutrients, but there was no advantage in methane production. The existence of $\mathrm{NaOH}$ not only eliminated the inhibition caused by microwave, but also improved the degree of degradation.
\end{abstract}

Keywords: sludge, microwave, alkaline, anaerobic digestion, pretreatment

\section{Introduction}

The activated sludge process is widely applied for treating municipal or industrial wastewater at wastewater treatment plants (WWTPs). The biggest challenge of this process is the large amount of waste-activated sludge (WAS) byproduct. In China, the treatment capacity for urban sewage increased from 74 million $\mathrm{m}^{3} / \mathrm{d}$ in 2004 to 151 million $\mathrm{m}^{3} / \mathrm{d}$ in 2014 [1], leading to a rapid

*e-mail: zhouhongjun@cup.edu.cn increase of WAS. The treatment and disposal of WAS cost up to $50 \%$ of the operating expense in WWTPs [2].

The main purpose of sludge treatment is to remove degradable material, water, and pathogens, thus reducing volume and mass of sludge as well as preventing pollution [3]. Anaerobic digestion (AD), which can not only achieve the above-stated purpose but also produce biogas as energy, is the most frequently used method for WAS treatment [4]. WAS consists of microbial cells, organic and inorganic matters, which are agglomerated as compact flocs by extracellular polymeric substances (EPS) and cations [5]. This composition and structure is 
resistant to $\mathrm{AD}$ due to slow and incomplete hydrolysis, resulting in long retention time (20-50 days) and low degradation efficiency (20-50\%) [5-6].

A pretreatment method can be employed to disintegrate the flocs so that the hydrolysis rate and the degradation degree of WAS will be improved. Some reviews have summarized and compared different kinds of mechanical, thermal, chemical, and biological treatment methods $[3,5,7]$. The low-impact pretreatment methods such as mechanical or biological generally increase speed of degradation, while high-impact methods such as thermal hydrolysis or oxidation are likely to improve both speed and degree of degradation [3]. Every single pretreatment method has its advantages and disadvantages. Hybrid techniques, which usually combine more than one physical and chemical method to achieve synergistic effects, are proven to further enhance the efficacy of AD by higher biogas production and solids reduction $[5,8]$. One of the promising hybrid methods is the combination of alkali and microwave pretreatment.

Alkali pretreatment is relatively simple, effective, and energy efficient, but when used alone it is usually unavoidably to add a high concentration of alkali in order to disrupt WAS completely. The excessive alkali will not only increase operating cost, but also bring corrosion and harm the active microorganisms in AD. Therefore, the treated sludge needs to be neutralized subsequently. While combined with a thermal pretreatment, chemical consumption can be reduced. Similarly, since alkali is helpful for sludge solubilization, heating efficiency can be improved significantly. Microwave is a form of electromagnetic radiation with a frequency range from $300 \mathrm{MHz}$ to $300 \mathrm{GHz}$, corresponding to wavelengths from $1 \mathrm{~m}$ to $1 \mathrm{~mm}$ [9]. Unlike the conventional heating methods, microwaves generate heat through the realignment of dipoles, which increases temperature uniformly and rapidly [7]. Besides the thermal effect, another potential mechanism of the microwave is the "athermal effect," referring to an effect that is unrelated to temperature rise (i.e., bond breakage caused by dipolar rotation of molecules) [7, 10]. The athermal effect is likely to dominate a low-intensity pretreatment, while the thermal effect plays a major role in a higher intensity pretreatment [11].

The combined alkali and microwave pretreatment has been proven to increase sludge solubilization and kill pathogens effectively [5, 7]. But whether pretreatment can improve the dewatering performance of the sludge is questionable. Doğan et al. [12] applied microwave (600 $\mathrm{W}, 16 \mathrm{~min})$ and $\mathrm{NaOH}(\mathrm{pH} 12,30 \mathrm{~min})$ pretreatment for WAS. Compared to the untreated sludge, methane production increased $53 \%$ and the digested sludge showed $22 \%$ improved dewaterability. Jang et al. [13] found that the solubilization in pretreated sludge was 18 times higher than in raw sludge, but saw no improvement in digested sludge dewaterability.

This hybrid technique is in its infancy. Further cost reduction and performance improvement are
Table 1. Properties of WAS and seeding sludge.

\begin{tabular}{|c|c|c|}
\hline Parameters & WAS & Seeding sludge \\
\hline $\mathrm{TS}(\mathrm{g} / \mathrm{L})$ & 27.4 & 33.6 \\
\hline $\mathrm{VS}(\mathrm{g} / \mathrm{L})$ & 11.8 & 9.5 \\
\hline $\mathrm{COD}(\mathrm{mg} / \mathrm{L})$ & 22,413 & 6,426 \\
\hline $\mathrm{NH}_{3}-\mathrm{N}(\mathrm{mg} / \mathrm{L})$ & 15.7 & 56.4 \\
\hline
\end{tabular}

important for its development. In this study, moderate conditions for alkali and microwave pretreatment were applied so that the energy consumption and operating expense could be reduced. Meanwhile, the treated WAS can be fed into digesters without neutralization. The method of central composite design (CCD) was employed for experiment design and condition optimization. The characteristics of digestion process and sludge were analyzed to evaluate the effects of the single as well as combined alkali and microwave pretreatment.

\section{Materials and Methods}

\section{Sludge}

The WAS used in this study was taken from a secondary sedimentation tank of a WWTP in Beijing, China. The seeding sludge was taken from a mesophilic anaerobic tank of WAS. The sludge samples were stored at $4^{\circ} \mathrm{C}$ to maintain freshness. The properties of WAS and seeding sludge are listed in Table 1.

\section{Optimizing Pretreatment and Modeling}

The microwave pretreatment was performed in a microwave equipment with a supplied power of $240 \mathrm{~W}$. Taking $\mathrm{NaOH}$ dosage (Factor A) as well as microwave processing time (Factor B) as the independent variables and methane production as the dependent variable, CCD was applied by the software Design Expert 8.0. The ranges of $\mathrm{NaOH}$ dosage and microwave processing time were set to be $0.07-0.20 \mathrm{~g} / \mathrm{g}$ TS and $4-10 \mathrm{~min}$, respectively. The numbers of non-center points and replicated center points were 8 and 4 , respectively. The $\alpha$ value was 1.414. Based on these settings, 12 runs of designed experiments are given in Table 2 .

$\mathrm{NaOH}$ was added into WAS for 24 hours. Then the sludge was treated by microwave, and the volume of each treatment was $50 \mathrm{~mL}$. The experiments of batch $\mathrm{AD}$ were taken in $250 \mathrm{~mL}$ bottles, with a volume ratio of seeding sludge and treated WAS of 1:1 (60 mL to $60 \mathrm{~mL})$. The bottles were incubated for 10 days at $120 \mathrm{rpm}$ and $37^{\circ} \mathrm{C}$. With the results of methane production, the model was constructed and analyzed by the Design Expert software. 
Table 2. Central composite design of combined alkali and microwave pretreatment for AD of WAS.

\begin{tabular}{|c|c|c|c|}
\hline $\begin{array}{c}\text { Run } \\
\text { No. }\end{array}$ & $\begin{array}{c}\text { Factor A: } \\
\text { NaOH dosage } \\
(\mathrm{g} / \mathrm{g} \text { TS })\end{array}$ & $\begin{array}{c}\text { Factor B: microwave } \\
\text { processing time } \\
(\mathrm{min})\end{array}$ & $\begin{array}{c}\text { Methane } \\
\text { production } \\
(\mathrm{mL})\end{array}$ \\
\hline 1 & 0.04 & 7.00 & 121 \\
\hline 2 & 0.07 & 4.00 & 126 \\
\hline 3 & 0.07 & 10.00 & 156 \\
\hline 4 & 0.14 & 2.76 & 132 \\
\hline 5 & 0.14 & 7.00 & 152 \\
\hline 6 & 0.14 & 7.00 & 162 \\
\hline 7 & 0.14 & 7.00 & 149 \\
\hline 8 & 0.14 & 7.00 & 169 \\
\hline 9 & 0.14 & 11.24 & 185 \\
\hline 10 & 0.20 & 4.00 & 104 \\
\hline 11 & 0.20 & 10.00 & 123 \\
\hline 12 & 0.23 & 7.00 & 97 \\
\hline
\end{tabular}

\section{Batch $\mathrm{AD}$ in 1.5 L Fermenters}

Through the model, we obtained the optimal conditions for combined alkali and microwave pretreatment. A set of four $1.5 \mathrm{~L}$ fermenters (1.5BG-4, Baoxing Bioengineering Equipment Company, Shanghai, China) were used to compare the batch $\mathrm{AD}$ of the untreated, microwave-, alkali-, and combined-treated WAS. The volume ratio of seeding sludge and WAS was 1:1 $(360 \mathrm{~mL}$ to $360 \mathrm{~mL}$ ). The digestion was operated for 10 days at $120 \mathrm{rpm}$ and $37^{\circ} \mathrm{C} . \mathrm{pH}$ was detected automatically. Every day, $10 \mathrm{~mL}$ liquid was sampled for analysis of soluble chemical oxygen demand (SCOD), volatile fatty acids (VFAs), and ammonia nitrogen $\left(\mathrm{NH}_{3}-\mathrm{N}\right)$. Before digestion, the structures of the untreated and treated sludge were observed by environmental scanning electron microscopy (ESEM, FEI Quanta 200, Holland). The main elements of the sludge before and after digestion were measured by energy-dispersive spectrometry (EDS) [14].

\section{Analytical Methods}

Total solid (TS), volatile solid (VS), SCOD, and $\mathrm{NH}_{3}-\mathrm{N}$ were analyzed according to standard methods [15]. The samples were filtered through $0.45 \mu \mathrm{m}$ filter before SCOD determination. Biogas yield was measured by the gas-collecting method of drainage-saturated $\mathrm{NaHCO}_{3}$. Methane concentration was analyzed by gas chromatography with a thermal conductivity detector and a TDX-01 packed column, using $\mathrm{H}_{2}$ as the carrier gas. The temperatures of the injector, column, and detector were $120^{\circ} \mathrm{C}, 100^{\circ} \mathrm{C}$, and $150^{\circ} \mathrm{C}$, respectively.

\section{Results and Discussion}

\section{Modeling and Optimizing Combined Alkali and Microwave Pretreatment for WAS}

For $\mathrm{NaOH}$ dosage, too little would not achieve good effect for cell dissolution, while too much might cause sodium ion and $\mathrm{pH}$ inhibition on $\mathrm{AD}$. In order to reduce operating costs and avoid subsequent neutralization,
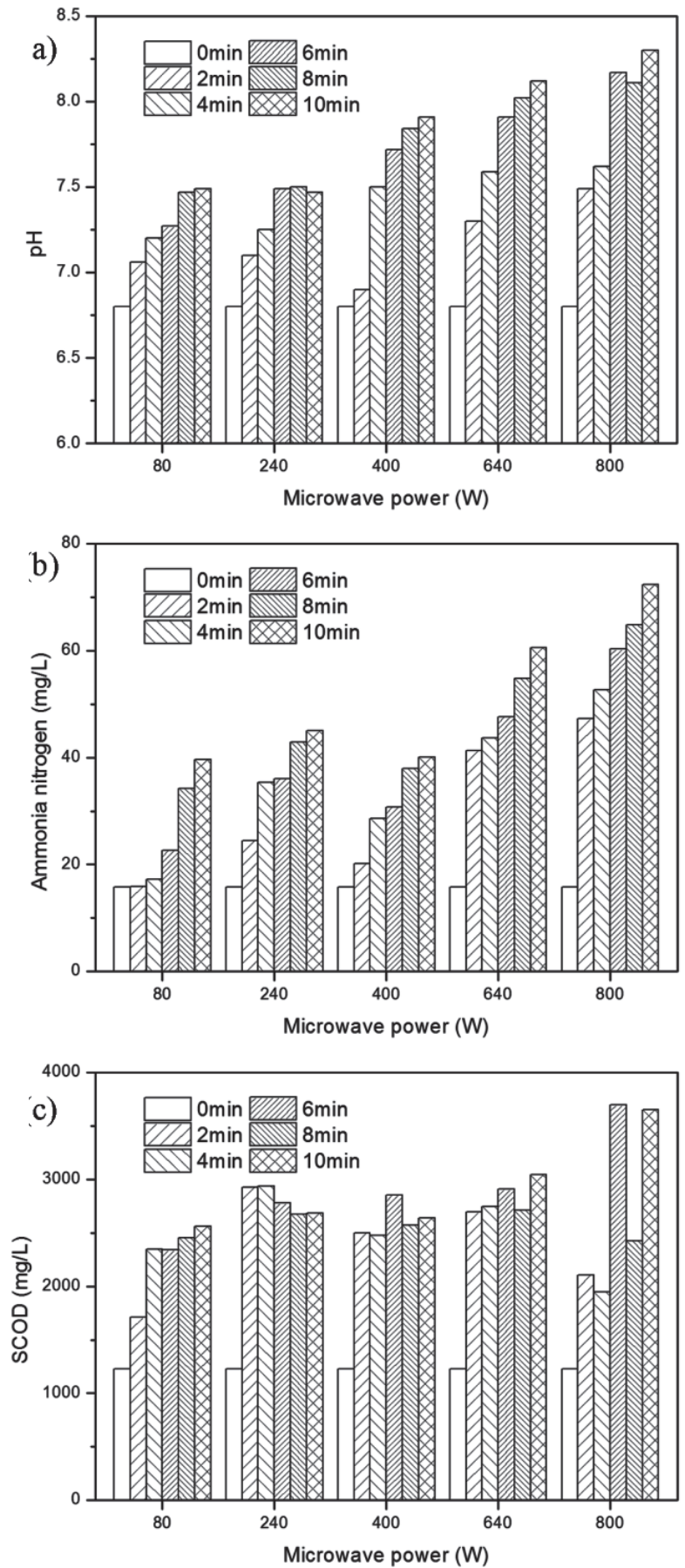

Fig. 1. a) $\mathrm{pH}, \mathrm{b}$ ) ammonia nitrogen, and c) SCOD variations of WAS after treatment by microwave with different power and irradiation time. 
Table 3. ANOVA for the model of combined alkali and microwave pretreatment.

\begin{tabular}{|c|c|c|c|c|c|}
\hline Source & Sum of squares & $\mathrm{df}$ & Mean square & F-value & $\mathrm{p}$-value \\
\hline Model & $7,364.19$ & 3 & $2,454.73$ & 37.73 & $<0.0001$ \\
\hline A & 988.82 & 1 & 988.82 & 15.20 & 0.0046 \\
\hline B & $1,920.55$ & 1 & $1,920.55$ & 29.52 & 0.0006 \\
\hline $\mathrm{A}^{2}$ & $4,454.82$ & 1 & $4,454.82$ & 68.47 & $<0.0001$ \\
\hline Residual & 520.48 & 8 & 65.06 & & 0.63 \\
\hline Lack of fit & 266.48 & 5 & 53.30 & & 0.6968 \\
\hline Pure error & 254.00 & 3 & 84.67 & & \\
\hline Cor total & $7,884.67$ & 11 & & & \\
\hline
\end{tabular}

Coefficient of determination $\mathrm{R}^{2}=0.934$

a longer processing time and lower $\mathrm{NaOH}$ concentration was preferred. The range of $\mathrm{NaOH}$ dosage was chosen according to previous papers [16-17], and a processing time of $24 \mathrm{~h}$ was applied.

The applied microwave power for treatment is $240 \mathrm{~W}$, which is moderate compared to conditions in other studies $[4,18]$. This value is determined based on preliminary experiments. A power range of $80 \mathrm{~W}$ to $800 \mathrm{~W}$ was used to treat WAS, and the variations of $\mathrm{pH}$ and ammonia nitrogen as well as SCOD are shown in Fig. 1. With the increase in microwave power and processing time, the $\mathrm{pH}$ and ammonia nitrogen of the treated sludge increased significantly, but still within the range of appropriate conditions for $\mathrm{AD}$. This change happened mainly because the intracellular substances including enzymes released, resulting in $\mathrm{pH}$ change and conversion of organic nitrogen compounds to ammonia nitrogen $[4,12,19]$. The SCOD also increased after microwave treatment, but when
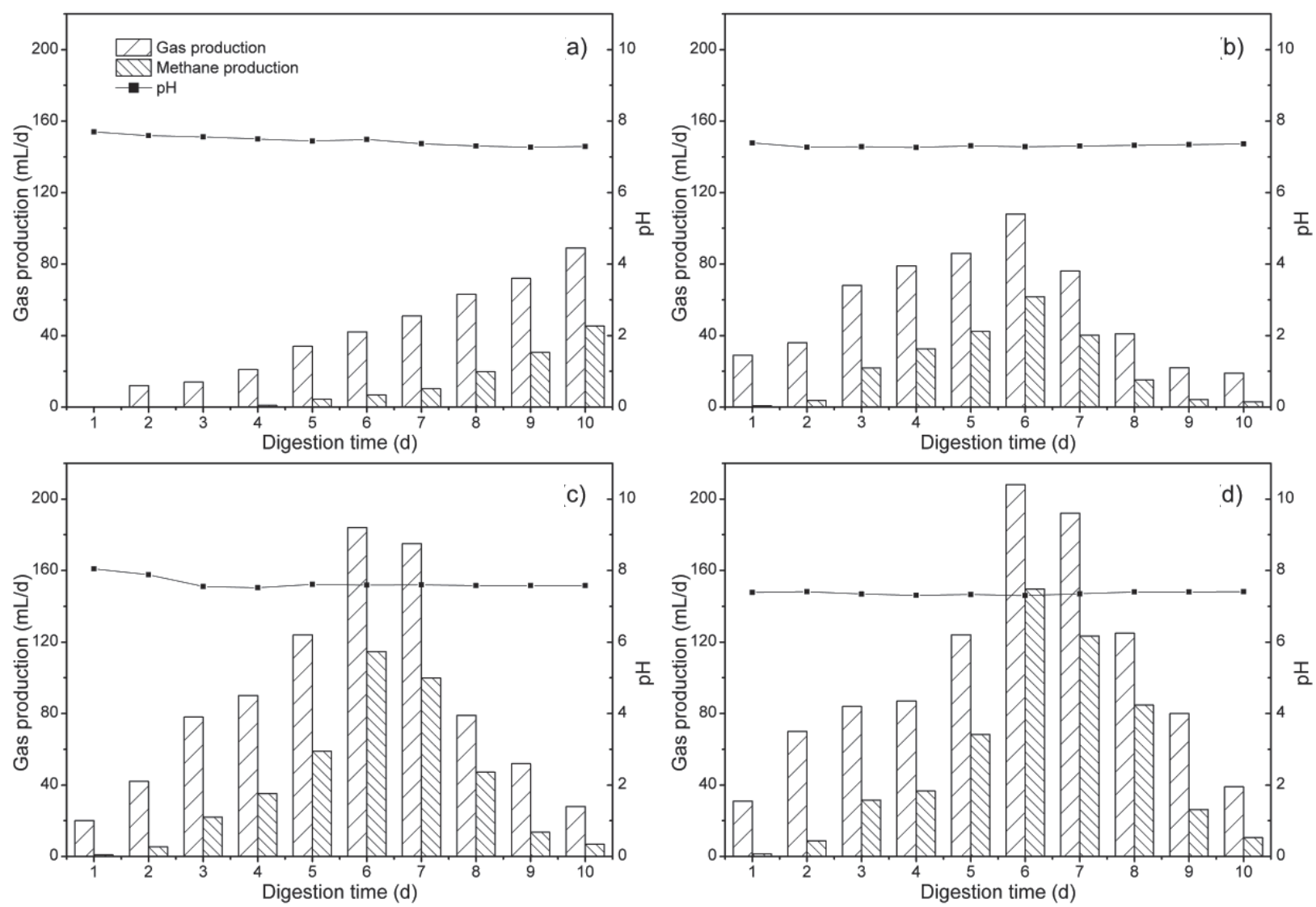

Fig. 2. Gas production, methane production, and $\mathrm{pH}$ of a) untreated, b) microwave-treated, c) alkali-treated, and d) combined alkali- and microwave-treated WAS during batch AD. 
the power was over $240 \mathrm{~W}$, SCOD did not significantly increase with enhanced processing power. Under the power of $800 \mathrm{~W}$, SCOD fluctuated obviously, which might be due to the severe boiling of WAS. Therefore, the power of $240 \mathrm{~W}$ is an economical and efficient choice.

Twelve experiments of AD were carried out under the designed conditions, and the obtained methane yields are listed in Table 2. According to these results, the quadratic model was suggested by the software, and A and B, as well as $\mathrm{A}^{2}$, were significant model terms. Therefore, the model equation is as follows in Equation 1:

$$
\mathrm{Y}=32.331+1480.9 \times \mathrm{A}-6118.3 \times \mathrm{A}^{2}+5.1647 \times \mathrm{B}
$$

...where $\mathrm{Y}$ is the predicted value of methane production $(\mathrm{mL})$, and $\mathrm{A}$ and $\mathrm{B}$ represent Factor $\mathrm{A}(\mathrm{NaOH}$ dosage, range of value: $0.07-0.20 \mathrm{~g} / \mathrm{g}$ TS) and Factor B (microwave processing time, range of value: 4-10 $\mathrm{min}$ ).

The analysis of variance (ANOVA) for this model is given in Table 3. The model F-value of 37.73 implies the model is significant. The Lack of Fit F-value of 0.63 implies the Lack of Fit is not significant relative to the pure error. The coefficient of determination $\mathrm{R}^{2}$ is 0.934 , which means that the model can explain up to $93.4 \%$ variability of the response. This analysis indicates the model is appropriate. As can be seen from Equation 1, in the range of microwave processing time, the longer the WAS is treated, the more methane it produces, while for $\mathrm{NaOH}$ dosage there is an optimum intermediate value. The optimization of the pretreatment conditions should be $0.12 \mathrm{~g} \mathrm{NaOH} / \mathrm{g}$ TS addition and $10 \mathrm{~min}$ microwave treatment.

\section{Effects of Pretreatment on AD Performance of WAS}

As shown in Fig. 2, these pretreatment methods can promote AD of WAS. During the 10-day digestion, the methane yields of untreated WAS, microwave-, alkali-, and combined-treated were 15.4, 29.4, 52.8, and $70.6 \mathrm{~mL} / \mathrm{g}$ VS, respectively. Compared to the former, the latter three increased to 1.9, 3.4, and 4.6 times, respectively. The peak of gas production appeared on day 6 for the treated sludge, while the untreated sludge had not peaked by day 10 . That is, low impact pretreatment methods can also simultaneously accelerate the hydrolysis step, but the degree of degradation is positively related to the intensity of pretreatment. This result is consistent with the summary made by Carrère et al. [3]. During digestion, the $\mathrm{pH}$ value was kept stable at around 7.4. Only the sludge treated by single $\mathrm{NaOH}$ showed $\mathrm{pH}$ over 8.0 at the beginning, but it was reduced later. Although alkali was also added in the WAS treated by combined method, the $\mathrm{pH}$ value did
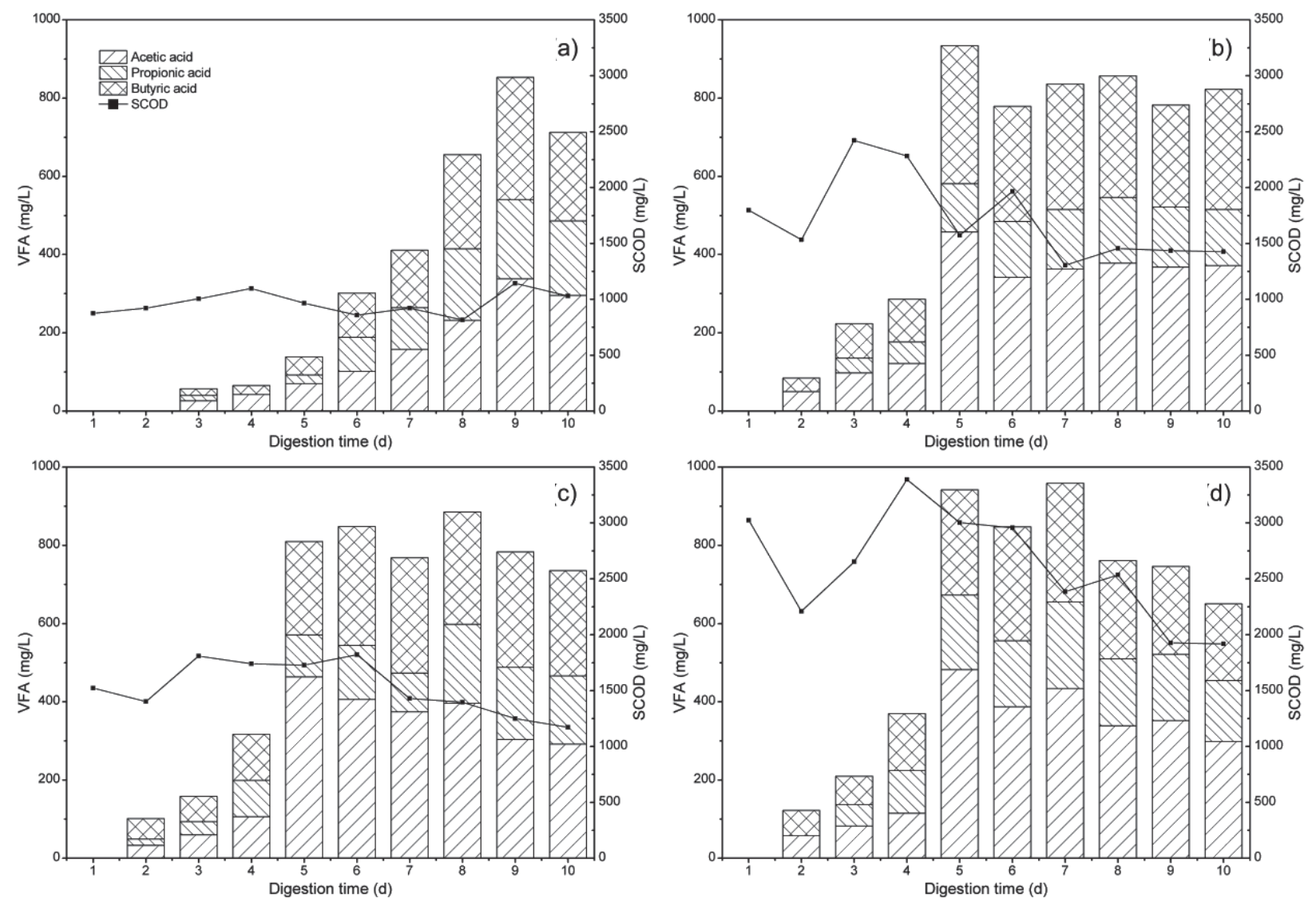

Fig. 3. VFA and SCOD of a) untreated, b) microwave-treated, c) alkali-treated, and d) combined alkali- and microwave-treated WAS during batch $\mathrm{AD}$. 


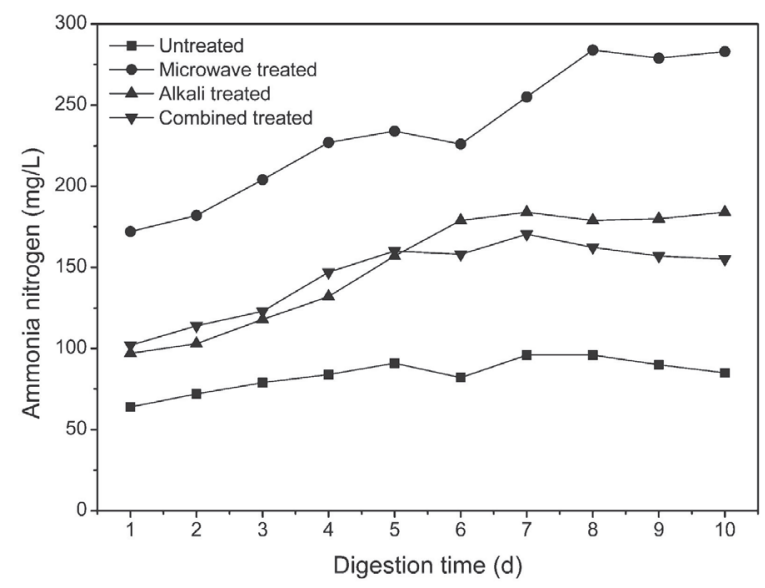

Fig. 4. Ammonia nitrogen of untreated and treated WAS during batch $\mathrm{AD}$

not increase, which might be due to microwaves releasing intracellular buffering substances.

The increase in SCOD after pretreatment can reflect the sludge disintegration degree $[6,19]$. As can be seen from Fig. 3, when WAS was treated by the microwave, alkali, and combined methods, SCOD achieved 206\%, $174 \%$ and $346 \%$ of that of untreated sludge, respectively. This indicates that under the effect of pretreatment, some extra- and intra-cellular biopolymers released from sludge flocs into the soluble phase [19]. After 10-day digestion, the SCOD removal rates of the three kinds of treated sludge were $20.6 \%, 23.0 \%$, and $36.5 \%$, respectively. The SCOD change showed a trend of increase in the early digestion, which may be due to the disrupted flocs, further releasing soluble organic matter. The SCOD removal rate of the untreated sludge was negative because its digestion had not reached the late stage in 10 days. VFAs, produced by fermentative bacteria, are important intermediate metabolites in $\mathrm{AD}$. The conversion rate of VFAs to methane in descending order is: HAc, butyric acid $(\mathrm{HBu})$, and propionic acid ( $\mathrm{HPa})$ [20]. In this study, the proportion of HAc was the highest, followed by $\mathrm{HBu}$ and HPa. The concentrations of VFAs were in proper ranges, which could not result in any acid inhibition.

Sewage sludge contains $2.4-5.0 \%$ TS nitrogen, existing mainly in the form of proteinaceous material [7]. Most pretreatment processes can cause nitrogen release [3]. As shown in Fig. 4, the concentration of $\mathrm{NH}_{3}-\mathrm{N}$ increased after pretreatment, and as digestion progressed, the increase continued. The WAS treated by a single microwave showed the highest $\mathrm{NH}_{3}-\mathrm{N}$ concentration, which was about three times that of the untreated sludge. Although the combined method included the same microwave treatment, the $\mathrm{NH}_{3}-\mathrm{N}$ release slowed down due to $\mathrm{NaOH}$ addition. In this study, the $\mathrm{NH}_{3}-\mathrm{N}$ concentrations were all below $300 \mathrm{mg} / \mathrm{L}$ and far from causing inhibition to AD [21].

For the WAS treated by single microwave, the value of VFA and SCOD was equivalent to that of single $\mathrm{NaOH}-$ treated sludge, but the methane yield was much lower,
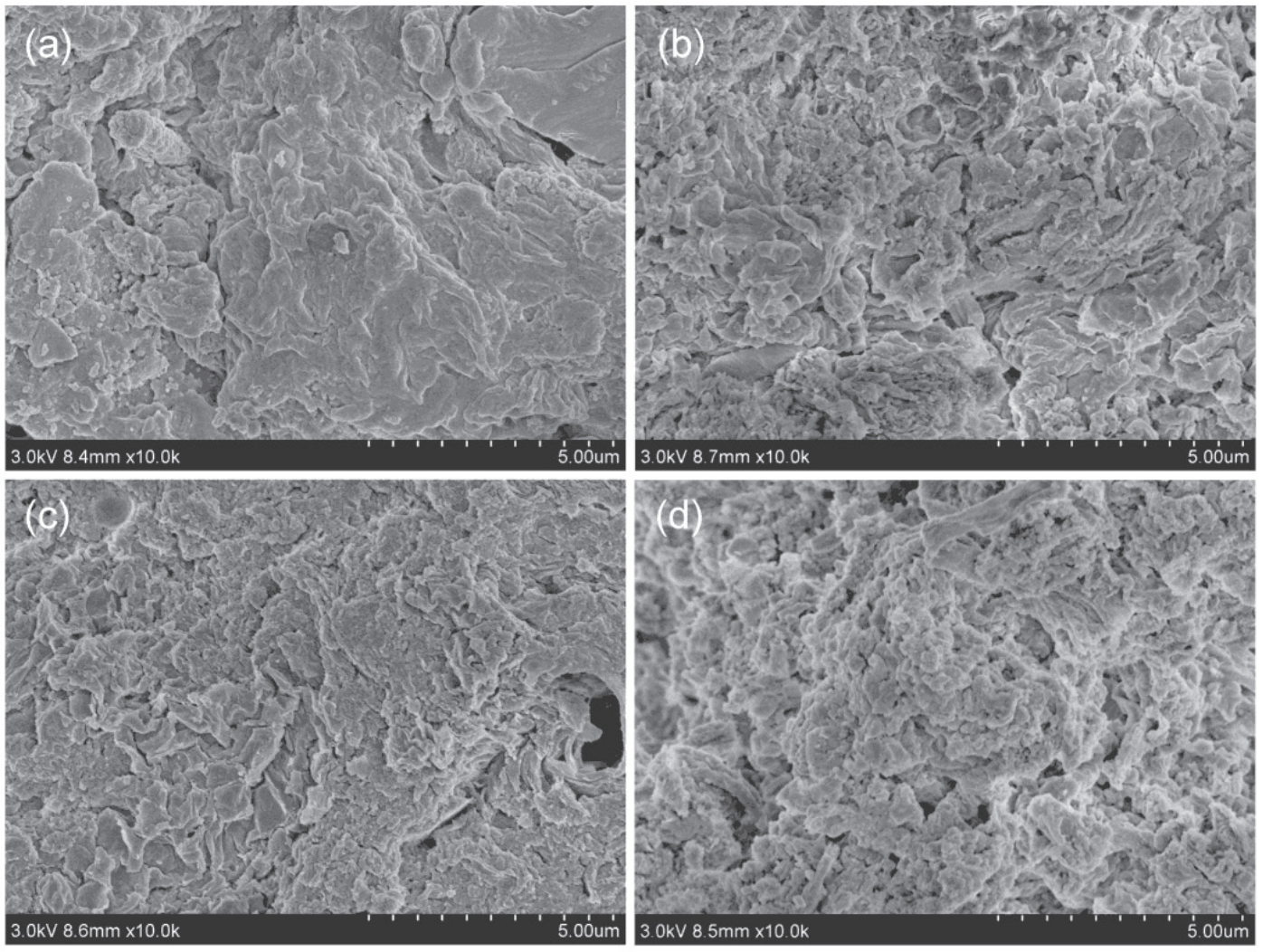

Fig. 5. ESEM images of a) untreated, b) microwave-treated, c) alkali-treated, and d) alkali- and microwave-treated WAS before AD. 
Table 4. EDS of sludge before AD.

\begin{tabular}{|c|c|c|c|c|c|}
\hline \multirow{2}{*}{ Element } & \multicolumn{5}{|c|}{ Weight \% } \\
\cline { 2 - 6 } & Seeding sludge & Untreated WAS & Microwave-treated WAS & NaOH-treated WAS & Combined-treated WAS \\
\hline $\mathrm{C}$ & 13.80 & 45.62 & 47.16 & 44.36 & 37.68 \\
\hline $\mathrm{O}$ & 47.68 & 40.39 & 40.70 & 44.60 & 41.36 \\
\hline $\mathrm{Na}$ & 0.19 & 0.53 & 0.57 & 1.97 & 1.49 \\
\hline $\mathrm{Mg}$ & 2.97 & 0.68 & 0.68 & 1.72 & 1.09 \\
\hline $\mathrm{Al}$ & 0.21 & 0.40 & 0.32 & 0.30 & 0.31 \\
\hline $\mathrm{Si}$ & 0.31 & 1.00 & 0.81 & 1.10 & 0.72 \\
\hline $\mathrm{S}$ & 0.58 & 1.82 & 1.83 & 0.26 & 3.84 \\
\hline $\mathrm{Cl}$ & 0.00 & 0.11 & 0.00 & 0.97 & 0.18 \\
\hline $\mathrm{K}$ & 0.26 & 0.82 & 0.59 & 2.59 & 1.49 \\
\hline $\mathrm{Ca}$ & 32.22 & 5.47 & 3.87 & 1.50 & 6.60 \\
\hline $\mathrm{Fe}$ & 1.78 & 3.16 & 1.84 & 0.00 & 2.77 \\
\hline $\mathrm{P}$ & 0.00 & 0.00 & 1.63 & & 2.48 \\
\hline
\end{tabular}

indicating that the activity of methanogenic bacteria had been inhibited. This can also be confirmed by the fact that the HAc content did not decrease during the later stage of $\mathrm{AD}$ (Fig. 3b). And based on the above analysis, the inhibitor should be neither acid nor ammonia.

\section{Effects of Pretreatment on Structure and Components of WAS}

The surface structure of the sludge was observed under ESEM, as shown in Fig. 5. The sludge treated by combined method was more dispersed, followed by the microwave-treated sludge. Compared to the untreated sludge, the surface texture of the alkali-treated sludge increased significantly. These images indicate that the pretreatment process has an obvious effect on breaking the flocs of WAS.

In order to estimate the influence of pretreatment and digestion on elements, EDS was applied for semiquantitative analysis. The results are listed in Tables 4 and 5. In the untreated sludge, besides the vast majority of carbon and oxygen, calcium and iron were elements with relatively high contents. For the sludge treated by alkali, not only sodium but also magnesium increased. Phosphorus arose in the sludge after being treated by the microwave and hybrid methods, indicating that microwave pretreatment can promote its release. Similar to the element nitrogen, phosphorus is also a major

Table 5. EDS of sludge after AD.

\begin{tabular}{|c|c|c|c|c|}
\hline \multirow{2}{*}{ Element } & \multicolumn{3}{|c|}{ Weight $\%$} \\
\cline { 2 - 5 } & Untreated WAS & Microwave treated WAS & NaOH treated WAS & Combined treated WAS \\
\hline $\mathrm{C}$ & 21.22 & 29.29 & 31.40 & 44.98 \\
\hline $\mathrm{O}$ & 45.25 & 44.45 & 43.00 & 37.44 \\
\hline $\mathrm{Na}$ & 0.42 & 0.38 & 0.59 & 0.84 \\
\hline $\mathrm{Mg}$ & 4.33 & 1.75 & 2.00 & 0.71 \\
\hline $\mathrm{Al}$ & 0.52 & 0.30 & 0.42 & 0.39 \\
\hline $\mathrm{Si}$ & 1.23 & 0.68 & 1.67 & 0.88 \\
\hline $\mathrm{S}$ & 0.30 & 2.46 & 1.71 & 5.09 \\
\hline $\mathrm{Cl}$ & 0.00 & 0.00 & 0.38 & 0.15 \\
\hline $\mathrm{K}$ & 0.16 & 0.75 & 0.79 & 1.10 \\
\hline $\mathrm{Ca}$ & 25.95 & 17.52 & 15.47 & 6.70 \\
\hline $\mathrm{Fe}$ & 0.62 & 2.42 & 2.56 & 1.72 \\
\hline
\end{tabular}


nutrient that exists in sludge in the form of protein [7]. Some studies have proven that microwave treatment can rapidly enhance the release of phosphate from sludge to supernatant [22-23]. After AD, no phosphorus was detected as being used up. As the calcium content in the seeding sludge was high, the EDS results after AD showed high calcium content; but the sludge treated by the hybrid method was an exception, suggesting that this substrate could let AD make better use of calcium. The sulfur content of combined treated sludge after AD was higher than others, which might be caused by a greater release and degradation of S-containing material in WAS.

\section{Conclusions}

The pretreatment process can significantly improve the biogas yield for $\mathrm{AD}$ of sludge. In order to reduce the operating costs, a moderate combined alkali and microwave pretreatment method is studied and evaluated. The CCD method was applied for experimental design and a quadratic model was established. The optimal pretreatment condition was $0.12 \mathrm{~g} \mathrm{NaOH} / \mathrm{g}$ TS treatment for $24 \mathrm{~h}$ and $240 \mathrm{~W}$ microwave treatment for $10 \mathrm{~min}$. Compared with the untreated sludge, either the single or hybrid pretreatments can accelerate the hydrolysis step, but the degree of degradation depends on treatment intensity. The combined alkali and microwave pretreatment showed the best effect, followed by the single alkali-treated method. The single microwave pretreatment can efficiently damage the sludge flocs and promote the release of biodegradable organics, but there is no advantage in methane production. The activity of methanogenic bacteria may get some kind of inhibition. Therefore, even under moderate conditions, the microwave is not suitable for individual pretreatment of WAS. But in the presence of $\mathrm{NaOH}$, not only can the inhibition caused by microwave be eliminated, but also the degree of degradation can be further improved. This combined method can enhance pretreatment efficiency at low cost and may have prospects for practical applications. In further study, the inhibition mechanism of microwave pretreatment as well as the synergism between $\mathrm{NaOH}$ and the microwave should be investigated deeply.

\section{Acknowledgements}

This work was supported by the National Natural Science Foundation of China (21406263), the Science Foundation of China University of Petroleum in Beijing (2462015YQ1303), and Beijing Municipal Science and Technology Project (D141100002814001).

\section{References}

1. National Bureau of Statistics of China. http://data.stats.gov. cn/index.htm.
2. LI H., LI C., LIU W., ZOU S. Optimized alkaline pretreatment of sludge before anaerobic digestion. Bioresource Technol. 123, 189, 2012.

3. CARRÈRE H., DUMAS C., BATTIMELLI A., BATSTONE D.J., DELGENÈS J.P., STEYER J.P., FERRER I. Pretreatment methods to improve sludge anaerobic degradability: a review. J. Hazard. Mater. 183 (1), 1, 2010.

4. KUGLARZ M., KARAKASHEV D., ANGELIDAKI I. Microwave and thermal pretreatment as methods for increasing the biogas potential of secondary sludge from municipal wastewater treatment plants. Bioresource Technol. 134, 290, 2013.

5. TYAGI V.K., LO S.-L. Application of physico-chemical pretreatment methods to enhance the sludge disintegration and subsequent anaerobic digestion: an up to date review. Rev. Environ. Sci. Bio. 10 (3), 215, 2011.

6. XU J., YUAN H., LIN J. Evaluation of thermal, thermalalkaline, alkaline and electrochemical pretreatments on sludge to enhance anaerobic biogas production. J. Taiwan Inst. Chem. E. 45 (5), 2531, 2014.

7. TYAGI V.K., LO S.-L. Microwave irradiation: A sustainable way for sludge treatment and resource recovery. Renew. Sust. Energ. Rev. 18, 288, 2013.

8. ANDREOTTOLA G., FOLADORI P. A review and assessment of emerging technologies for the minimization of excess sludge production in wastewater treatment plants. J. Environ. Sci. Heal. A. 41 (9), 1853, 2006.

9. BANIK S., BANDYOPADHYAY S., GANGULY S. Bioeffects of microwave-a brief review. Bioresource Technol. 87 (2), 155, 2003.

10. ESKICIOGLU C., TERZIAN N., KENNEDY K.J., DROSTE R.L., HAMODA M. Athermal microwave effects for enhancing digestibility of waste activated sludge. Water Res. 41 (11), 2457, 2007.

11. CELLA M.A., AKGUL D., ESKICIOGLU C. Assessment of microbial viability in municipal sludge following ultrasound and microwave pretreatments and resulting impacts on the efficiency of anaerobic sludge digestion. Appl. Microbiol. Biot. 100 (6), 2855, 2016.

12. DOĞAN I., SANIN F.D. Alkaline solubilization and microwave irradiation as a combined sludge disintegration and minimization method. Water Res. 43 (8), 2139, 2009.

13. JANG J.-H., AHN J.-H. Effect of microwave pretreatment in presence of $\mathrm{NaOH}$ on mesophilic anaerobic digestion of thickened waste activated sludge. Bioresource Technol. 131, 437, 2013.

14. LI Z., JIANG N., WU F., ZHOU Z. Experimental investigation of phosphorus adsorption capacity of the waterworks sludges from five cities in China. Ecol. Eng. 53, 165, 2013.

15. APHA, AWWA, WEF (eds.) Standard methods for the examination of water and wastewater. American Public Health Association (APHA), American Water Work Association (AWWA) and Water Environment Federation (WEF), Washington, DC, 2005.

16. LIN Y., WANG D., WU S., WANG C. Alkali pretreatment enhances biogas production in the anaerobic digestion of pulp and paper sludge. J. Hazard. Mater. 170 (1), 366, 2009.

17. CHI Y., LI Y., FEI X., WANG S., YUAN H. Enhancement of thermophilic anaerobic digestion of thickened waste activated sludge by combined microwave and alkaline pretreatment. J. Environ. SCI. 23 (8), 1257, 2011.

18. APPELS L., HOUTMEYERS S., DEGRĖVE J., VAN IMPE J., DEWIL R. Influence of microwave pre-treatment 
on sludge solubilization and pilot scale semi-continuous anaerobic digestion. Bioresource Technol. 128, 598, 2013.

19. ESKICIOGLU C., KENNEDY K.J., DROSTE R.L. Characterization of soluble organic matter of waste activated sludge before and after thermal pretreatment. Water Res. 40 (20), 3725, 2006.

20. WANG Y., ZHANG Y., WANG J., MENG L. Effects of volatile fatty acid concentrations on methane yield and methanogenic bacteria. Biomass and Bioenergy. 33 (5), 848, 2009.

21. FNR: Guide to Biogas-From production to use. Fachagentur Nachwachsende Rohstoffe e. V. (FNR), Gülzow, 2010.
22. CHAN W.I., WONG W.T., LIAO P.H., LO K.V. Sewage sludge nutrient solubilization using a single-stage microwave treatment. J. Environ. Sci. Heal. A. 42 (1), 59, 2007.

23. WONG W.T., CHAN W.I., LIAO P.H., LO K.V., MAVINIC D.S. Exploring the role of hydrogen peroxide in the microwave advanced oxidation process: solubilization of ammonia and phosphates. J. Environ. Eng. Sci. 5 (6), 459, 2006. 